\title{
Essential role for caspase 8 in T-cell homeostasis and T-cell-mediated immunity
}

\author{
Leonardo Salmena, ${ }^{1,2,3}$ Benedicte Lemmers, ${ }^{1,2,3}$ Anne Hakem, ${ }^{1,2,3}$ Elzbieta Matysiak-Zablocki, ${ }^{1,2,3}$ \\ Kiichi Murakami, ${ }^{2,3}$ P.Y. Billie Au, 1,2,3 Donna M. Berry, ${ }^{3,4}$ Laura Tamblyn, 1,2,3 \\ Amro Shehabeldin, ${ }^{1,2,3}$ Eva Migon, ${ }^{1,2,3}$ Andrew Wakeham, ${ }^{1,2}$ Denis Bouchard, ${ }^{1,2}$ Wen Chen Yeh, ${ }^{1,2,3}$ \\ Jane C. McGlade, ${ }^{3,4}$ Pamela S. Ohashi, ${ }^{2,3}$ and Razqallah Hakem ${ }^{1,2,3,5}$ \\ ${ }^{1}$ The Advanced Medical Discovery Institute (AMDI), ${ }^{2}$ Ontario Cancer Institute, and ${ }^{3}$ Department of Medical Biophysics, \\ University of Toronto, Toronto, Ontario M5G 2C1, Canada; ${ }^{4}$ The Arthur and Sonia Labatt Brain Tumor Research Center, \\ The Hospital for Sick Children, Toronto, Ontario M5G 1X8, Canada
}

Defects in death receptor-mediated apoptosis have been linked to cancer and autoimmune disease in humans. The in vivo role of caspase 8, a component of this pathway, has eluded analysis in postnatal tissues because of the lack of an appropriate animal model. Targeted disruption of caspase 8 is lethal in utero. We generated mice with a targeted caspase 8 mutation that is restricted to the T-cell lineage. Despite normal thymocyte development in the absence of caspase 8 , we observed a marked decrease in the number of peripheral T-cells and impaired T-cell response ex vivo to activation stimuli. caspase 8 ablation protected thymocytes and activated T-cells from CD95 ligand but not anti-CD3-induced apoptosis, or apoptosis activated by agents that are known to act through the mitochondria. caspase 8 mutant mice were unable to mount an immune response to viral infection, indicating that caspase 8 deletion in T-cells leads to immunodeficiency. These findings identify an essential, cell-stage-specific role for caspase 8 in T-cell homeostasis and T-cell-mediated immunity. This is consistent with the recent identification of caspase 8 mutations in human immunodeficiency.

[Keywords: Caspase 8; conditional mutation; T-cells; homeostasis; apoptosis; CD95]

Received December 2, 2002; revised version accepted February 18, 2003.

The active elimination of cells in multicellular organisms during normal development, differentiation, and tissue homeostasis is facilitated by apoptosis (Meier et al. 2000; Newton et al. 2000; Rathmell et al. 2002). Apoptosis also serves to remove cells that pose a threat to the survival of an organism. Two major apoptotic pathways have been identified: the mitochondrial pathway and the death receptor (DR) pathway (Strasser et al. 1995). Both pathways are dependent on the activation of downstream caspases, a family of aspartate-specific cysteine proteases, for the proper execution of apoptosis (Earnshaw et al. 1999; Gross et al. 1999; Krammer 2000; Wang 2001).

In the immune system, apoptosis is critical for lymphocyte development and homeostasis (Lenardo et al. 1999; Nagata 1999; Rathmell and Thompson 2002) For example, elimination of autoreactive $\mathrm{T}$ - and B-cells by apoptosis, a process known as negative selection, is re-

${ }^{5}$ Corresponding author.

E-MAIL rhakem@uhnres.utoronto.ca; FAX (416) 204-2277.

Article published online ahead of print. Article and publication date are at http://www.genesdev.org/cgi/doi/10.1101/gad.1063703. quired for establishment and maintenance of self-tolerance (Germain 2002; Rathmell and Thompson 2002). Apoptosis is also essential for the down-regulation of immune responses by eliminating activated T-cells after their initial expansion, a process known as activationinduced cell death (AICD; Budd 2001).

Defects in DR-mediated apoptosis result in autoimmune disease in humans and mice. The Autoimmune Lymphoproliferative Syndrome (ALPS) is a human childhood condition, characterized clinically by lymphoadenopathy, splenomegaly, autoimmune hemolytic anemia, thrombocytopenia, and hypergammaglobinemia (Lenardo et al. 1999; Straus et al. 1999). The majority of ALPS patients have dominant mutations in the genes encoding the CD95 (FAS/APO-1) receptor, the CD95 ligand (CD95L), and caspase 10 (Lenardo et al. 1999; Straus et al. 1999; Wang et al. 1999). These mutations have been associated with the survival and the expansion of an autoreactive population of $\mathrm{Thy}^{+}{ }^{+} \mathrm{B} 220^{+} \mathrm{CD} 4^{-} \mathrm{CD} 8^{-}$, which may be responsible for the observed autoimmunity (Lenardo et al. 1999; Straus et al. 1999). In mice, spontaneous mutations of CD95 and CD95L result in similar syndromes recognized as lymphoproliferation (lpr) and gen- 
eralized lymphoproliferative disease (gld; Nagata and Suda 1995).

Caspase 8 (Flice/Mach/Mch5) is essential for apoptosis induced by DRs CD95, TNFR1, and DR3, DR4, and DR5 in various cell systems (Juo et al. 1998; Varfolomeev et al. 1998; Bodmer et al. 2000; Ashkenazi 2002). Binding of the CD95 receptor (by its ligand, CD95L) stimulates the recruitment of the adaptor molecule Fas-associated death domain (FADD/Mort-1) and caspase 8 to the receptor, forming the Death-Inducing Signaling Complex (DISC; Krammer 2000). Recruitment of many procaspase 8 molecules to the DISC is thought to facilitate self-processing and formation of the active caspase $8 \mathrm{en}$ zyme (Salvesen 1999). Consequently, active caspase 8 induces apoptosis by triggering the activation of downstream caspases 2, 3, 6, and 7 (Budihardjo et al. 1999). Furthermore, active caspase 8 can cleave Bid, a pro-apoptotic member of the Bcl-2 family, generating a truncated Bid polypeptide (tBid), which translocates to the mitochondrial membrane and triggers cytochrome $c$ release and activation of the mitochondrial apoptotic pathway (Luo et al. 1998; Budihardjo et al. 1999; Kuwana et al. 2002). Present knowledge implies that all specific substrates for caspase 8 are involved in the induction of apoptosis.

In addition to its importance in the induction of apoptosis, recent studies have implicated the DR pathway and its components in the regulation of lymphocyte proliferation (Budd 2002). For example, T-cells expressing a dominant interfering form of FADD are specifically deficient in cytokine-mediated proliferation (Newton et al. 1998; Walsh et al. 1998; Zornig et al. 1998). Similarly, $F A D D^{-/-}$T-cells derived from Rag-1 ${ }^{-1-}$ mice reconstituted with $F A D D^{-1-}$ ES cells exhibit defective proliferation (Zhang et al. 1998). Additionally, another component of the DISC, c-FLIP $(\mathrm{L})$, has been reported to increase T-cell proliferation by modulating T-cell receptor signaling (Lens et al. 2002). A role for caspases in T-cell proliferation has been suggested from studies using inhibitors of caspases (Alam et al. 1999; Kennedy et al. 1999; Mack and Hacker 2002).

A report by Chun et al. (2002) has identified two patients with ALPS-like disorders who have normal CD95, CD95L, or caspase 10 genes. These patients, however, had a C-to-T mutation in the caspase 8 gene that reduced protein stability and abrogated the enzymatic activity of the caspase 8 protein (Chun et al. 2002). In contrast to other ALPS patients with mutations in CD95, CD95L, or caspase 10 genes, the two caspase 8 mutant patients exhibited reduced T-cell activation and proliferation, natural killer cell activation, and immunoglobulin production.

The in vivo role of caspase 8 in adult tissues remains poorly understood because of the embryonic lethality associated with caspase 8 deletion in mice. Despite the exciting findings by Chun et al. (2002) in patients with mutant caspase 8 , the in vivo specific function of caspase 8 still remains uncertain. The residual function of "protease dead' caspase 8 is not known. Compensatory roles for caspase 10 in humans with mutant caspase 8 cannot be adequately addressed at the present time.
The phenotypes associated with caspase 8 and caspase 10 mutations in humans are based on limited genetic data. Furthermore, mutation of caspase 8 in all cells, as seen in humans caused by germ-line mutation, may complicate the study of its specific roles in lymphocytes. We report the generation of mice bearing a caspase 8 mutation specifically targeted to the T-cell lineage. We show that caspase 8 mutation abrogated CD95-induced apoptosis but did not affect apoptosis activated through the mitochondria. Finally, we demonstrate that caspase 8 is dispensable for thymocyte development; however, it is essential for T-cell homeostasis, activation-induced Tcell responses in vitro, and T-cell-mediated immunity.

\section{Results}

Generation of mice with a floxed caspase 8 allele

A targeting construct was generated in which exons 3 and 4 of caspase 8 , a neomycin resistance cassette, and the herpes simplex virus thymidine kinase gene were each flanked by LoxP sites (Fig. 1A). The linearized construct was electroporated into E14K embryonic stem (ES) cells, and G418-resistant clones were selected. Four independent clones with insertion of the targeting vector by homologous recombination at the caspase 8 locus were obtained and confirmed by Southern blot analysis (Fig. 1A,B). To remove the floxed PGKneor-PGKtk cassettes, two independent casp $8^{f 13-4 ; n e o-t k / w t}$ ES clones were transiently transfected with a CMV-driven construct encoding Cre recombinase (Fig. 1C). Four different clones that had lost the PGKneo ${ }^{r}$-PGKtk cassettes but retained the floxed caspase 8 exons 3 and $4\left(\operatorname{casp}^{f 13-4}\right)$ were injected into $\mathrm{C} 57 \mathrm{BL} / 6$ blastocysts to generate chimeric mice. Heterozygous (casp $\left.8^{f l 3-4 / w t}\right)$ mutant mice were generated by crossing chimeras to C57BL/6 mice (Fig. 1D). Intercrossing of heterozygous casp $8^{\text {fli-4/wt }}$ mice generated homozygous casp $8^{f 13-4 / f 13-4}$ mice in the predicted Mendelian ratio. casp $8^{\text {fl3-4/f13-4 }}$ mice were healthy and indistinguishable from their control littermates.

To confirm that in vivo Cre-mediated deletion of caspase 8 exons 3 and 4 results in a nonfunctional allele, we generated mice carrying a germ-line mutation of caspase $8\left(\operatorname{casp} 8^{\Delta 3-4 / w t}\right)$ by crossing casp $8^{f 13-4 / w t}$ mice to $C M V$-Cre transgenic mice. In this transgenic strain, deletion of LoxP-flanked DNA occurs in all tissues, including germ cells (Su et al. 2002). No homozygous casp $8^{\Delta 3-4 / \Delta 3-4}$ mice were obtained from interbreeding of heterozygotes $\operatorname{casp} 8^{\Delta 3-4 / w t}$ mice (data not shown). Additionally, analysis of embryos at different days of gestation indicated that $\operatorname{casp} 8^{\Delta 3-4 / \Delta 3-4}$ mutants did not survive past embryonic day 12.5 (E12.5). The embryonic lethality observed before E12.5 with the casp $8^{\Delta 3-4}$ mutation was consistent with previously reported caspase 8 deletion in mice (Varfolomeev et al. 1998; Sakamaki et al. 2002).

\section{Conditional disruption of caspase 8 in the T-cell lineage}

To inactivate caspase 8 in the T-cell lineage, casp $8^{f l 3-4 / w t}$ mice were mated to LckCre transgenic mice (C57BL/6 


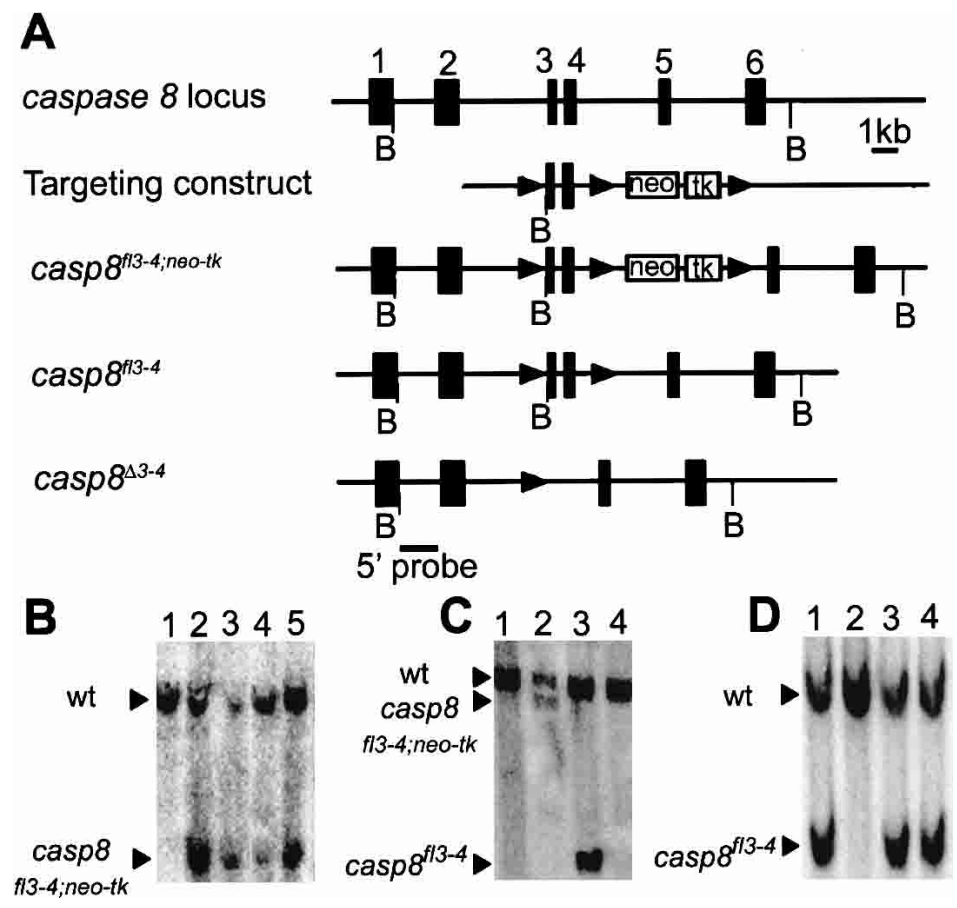

Figure 1. Generation of conditional caspase 8 mutant mice. (A) Schematic representation of the wild-type caspase 8 locus, the targeting construct, and the caspase 8 mutant alleles casp $8^{f 13-4 ; \text { neo-tk }}, \operatorname{casp} 8^{f 13-4}$, and casp $8^{\Delta 3-4}$. Exons are indicated as filled boxes and LoxP sites as triangles. B, BamHI site. $(B)$ Four independent clones carrying homologous recombination to the caspase 8 locus were identified by PCR and confirmed by Southern blot with the $5^{\prime}$ probe. (Lane 1) Wild-type ES DNA. (Lanes 2-5) casp $8^{\text {fl3-4;neo-tk }}$ ES clones. (C) casp $8^{f l 3-4, n e o-t k}$ ES clones were transiently transfected with a $C M V$-driven construct encoding for Cre recombinase. Clones that have lost the neo-tk cassettes but retained the floxed caspase 8 exons 3 and $4\left(\right.$ casp $\left.^{813-4}\right)$ were identified by Southern blot with exons 3-4. (Lane 1) Wild-type ES clone. (Lane 2) casp $8^{f 13-4 ; n e o-t k / w t}$ ES clone. (Lane 3) casp $8^{f l 3-4 / w t}$ ES clone. (Lane 4) casp $8^{\Delta 3-4 / w t}$ ES clone. (D) Heterozygous $\left(\right.$ casp $\left.8^{f 13-4 / w t}\right)$ mutant littermate mice were identified by Southern blot on tail DNA with a $5^{\prime}$-flanking probe. (Lanes $1,3,4$ ) casp $8^{f 13-4 / w t}$. (Lane 2) Wild type. BamHI restriction fragments (detected by $5^{\prime}$ probe): wild-type fragment $=9.4$ $\mathrm{kb} ; \quad \operatorname{casp} 8^{f 13-4 ; n e o-t \mathrm{k}}=8.7 \mathrm{~kb} ; \operatorname{casp} 8^{f 13-4}=4.5 \mathrm{~kb}$; and $\operatorname{casp} 8^{\Delta 3-4}=9.0 \mathrm{~kb}$.

background), which express Cre recombinase under the control of the T-cell-specific Lck promoter (Hennet et al.

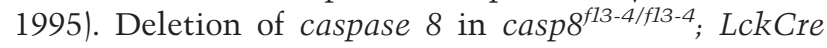
mice (T-cell-lineage-specific caspase 8 mutant mice; referred to in this paper as tcasp $8^{-/-}$) was restricted to the $\mathrm{T}$-cell lineage. Southern blot analysis indicated a specific and complete deletion of exons 3 and 4 of caspase 8 from thymocytes and peripheral T-cells in comparison to tail DNA, which retained the floxed exons 3 and 4 (Fig. 2A; data not shown). Sequencing of the mutant cDNA revealed that the $\operatorname{casp} 8^{\Delta 3-4}$ transcript contained a frameshift mutation that introduced several termination codons into the open reading frame of caspase 8 (Fig. 2B). Thus, the $\operatorname{casp} 8^{\Delta 3-4}$ transcript if stable, would encode for a $\mathrm{N}$-terminal peptide of 182 amino acids, in contrast to the wild-type caspase 8 protein made up of 480 amino acids. Western blots performed on cell extracts derived from wild-type and tcasp $8^{-/-}$total thymocytes using a polyclonal antisera specific for the C-terminal p10 domain of caspase 8 did not detect caspase 8 in tcasp $8^{-/-}$ T-cells (Fig. 2C). These results in addition to a lack of phenotype in the casp $8^{f 13-4 / w t}$; LckCre mice suggest that casp $8^{\Delta 3-4}$ produces either a null mutation, or alternatively, if an N-terminal peptide is made, it is not acting in a dominant-negative manner.

\section{Caspase 8 is dispensable for thymocyte development}

To identify a potential role for caspase 8 in thymocyte development, thymocytes from tcasp $8^{-/-}$and control littermate mice were analyzed by flow cytometry. CD4 ${ }^{-}$ $\mathrm{CD}^{-}, \mathrm{CD}^{+} \mathrm{CD}^{+}, \mathrm{CD}^{+} \mathrm{CD}^{-}$, and $\mathrm{CD} 4^{-} \mathrm{CD} 8^{+}$thymocyte subpopulations were similarly represented in tcasp $8^{-/-}$and control mice (Fig. 2D). Also, the total num- ber of the different thymocyte subpopulations was not significantly different in tcasp $8^{-/-}$and control mice (Fig. $2 \mathrm{E}$; data not shown). Finally, the expression levels of TCR $\alpha \beta, C D 3, C D 25, C D 44, C D 95$, and CD95L were similar in the tcasp $8^{-/-}$and control mice (data not shown). Together, these findings suggest that caspase 8 function is dispensable for normal thymocyte development.

Caspase 8 is required for CD95-, but not mitochondria-mediated apoptosis in the T-cell lineage

We investigated the effect of caspase 8 mutation on Tcell lineage death induced through the DR and the mitochondrial apoptotic pathways. Thymocytes and activated T-cells were challenged with various apoptotic stimuli-anti-CD95, CD95L, $\gamma$-irradiation, dexamethasone, and anti-CD3 antibody. The role of caspase 8 deficiency on apoptosis induced by neglect in media was also investigated. tcasp $8^{-/-}$thymocytes and activated T-cells were resistant to death mediated by anti-CD95 antibody and CD95L (Fig. 3A,B; data not shown). However, tcasp $8^{-/-}$and control thymocytes and activated T-cells exhibited similar sensitivity when apoptosis was induced by $\gamma$-irradiation, dexamethasone, and anti-CD3 and anti-CD28 antibodies or by neglect in media (Fig. $3 \mathrm{~A}, \mathrm{~B})$.

Western blots were performed to further characterize the apoptotic response in the absence of caspase 8 . The processing of caspase 3 and Bid were monitored in thymocytes after treatment with CD95L or $\gamma$-irradiation (Fig. 3C). In contrast to controls, tcasp $8^{-/-}$thymocytes treated with CD95L did not show an increase in the processing of either caspase 3 or Bid (Fig. 3C). Pro-caspase 3 


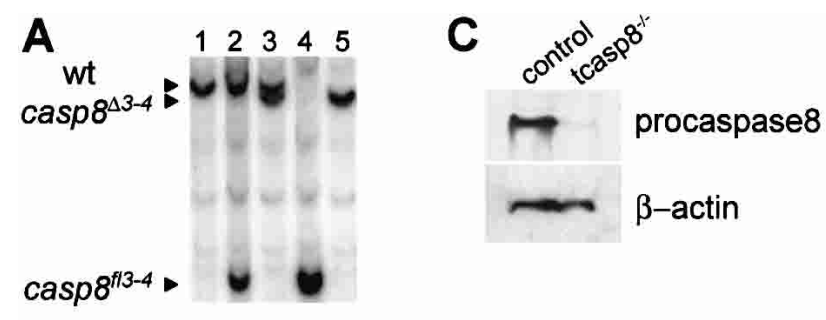

B

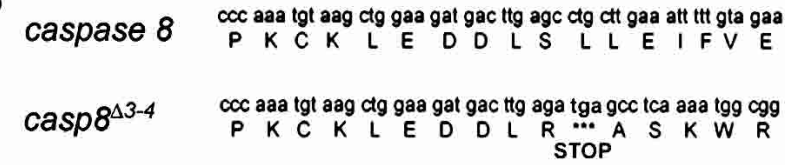

D

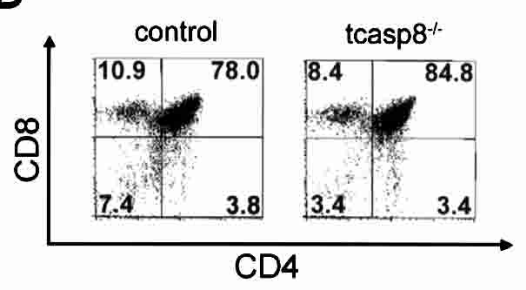

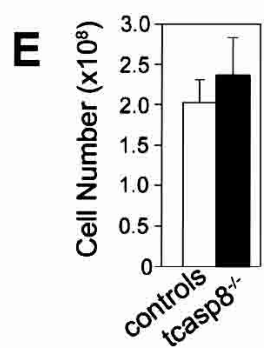

Figure 2. Deletion of caspase 8 in the T-cell lineage. (A) Southern blot performed on BamHI-digested genomic DNA extracted from tcasp $8^{-1-}$ mice shows a specific and complete deletion of exons 3 and 4 of caspase 8 in thymocytes in comparison to tail extracted DNA. (Lane 1) Wild-type tail DNA. (Lane 2) casp $8^{f 13-4 / w t}$; LckCre tail DNA. (Lane 3) casp $8^{f 13-4 / w t}$; LckCre thymocyte DNA. (Lane 4) tcasp $8^{-/-}$tail DNA. (Lane 5) tcasp $8^{-1-}$ thymocyte DNA. (B) The $\operatorname{casp} 8^{\Delta 3-4}$ nucleotide sequence contained several termination codons that disrupted the open reading frame of caspase 8 shortly beyond exon 2. (C) Western blot performed on thymocyte cell extracts derived from control and tcasp $8^{-/-}$mice confirmed the absence of caspase 8 protein in thymocytes. $(D)$ Representative dot blots showing similar thymocyte populations in tcasp $8^{-1-}$ and control mice. (E) Mean total thymocyte numbers in tcasp $8^{-/-}$and control mice $(n=17$, $p=0.601$.

and Bid were equally processed in tcasp $8^{-/-}$and control thymocytes in response to $\gamma$-irradiation or dexamethasone (Fig. 3C; data not shown). The low level of cleavage of caspase 3 observed in the tcasp $8^{-/-}$thymocytes at 4 and $8 \mathrm{~h}$ (with or without CD95L) is a caspase-8-independent event that may be a result of culturing these cells in the absence of the necessary survival factors.

The level of p53 protein was assessed as a control for the cellular response to $\gamma$-irradiation and was found to be unaffected by caspase 8 deficiency. Taken together, these results demonstrate that caspase 8 is necessary for CD95-mediated death of thymocytes and activated Tcells, but does not impact T-cell death in response to apoptotic stimuli that target the mitochondrial pathway, nor does it protect from anti-CD3-mediated AICD or death resulting from lack of survival factors. Furthermore, caspase 8 is essential for caspase 3 and Bid processing when apoptosis is activated through the CD95 receptor but not when apoptosis is induced via the mitochondrial pathway with $\gamma$-irradiation or dexamethasone.
Caspase 8 is essential for peripheral T-cell homeostasis

Mutation of human CD95, CD95L, or caspase 10 leads to ALPS associated with splenomegaly, lymphoadenopathy, and the accumulation of a Thy $1^{+} \mathrm{CD}^{-}{ }^{-} \mathrm{CD} 8^{-} \mathrm{B} 220^{+}$ T-cell population (Lenardo et al. 1999; Straus et al. 1999). Similarly, lymphoadenopathy and splenomegaly are characteristics of mice with lpr and gld disease (Nagata 1999). Unexpectedly, we observed a general decrease in the proportion of Thy $1.2^{+}$peripheral cells in tcasp $8^{-1-}$ mice relative to their control littermates (Fig. 4A). The relative proportion (percent \pm S.T.E.) of splenic T-cells was significantly lower in tcasp $8^{-/-}$mice compared with control mice $(6.5 \% \pm 0.8 \%$ vs. $16.9 \% \pm 2.3 \% ; n=16$, $p=0.00011$ ). In lymph nodes (LN), the proportion of Tcells was also significantly lower $37.1 \% \pm 3.9 \%$ vs. $65.6 \% \pm 3.8 \% ; n=17, p<0.0001)$ in tcasp $8^{-1-}$ versus control mice, respectively. These results were supported by histological analysis of tcasp $8^{-/-}$spleens, which showed a reduced level of staining for follicular T-cells (Fig. 4B). The total number of splenic lymphocytes was not affected by the deletion of caspase 8. However, the total number of T-cells was significantly lower $\left(1.1 \pm 0.2 \times 10^{7}\right.$ vs. $\left.3.6 \pm 1.1 \times 10^{7} ; n=9, p=0.045\right)$ in tcasp $8^{-1-}$ versus control mice (Fig. 4C). Furthermore, the $\mathrm{CD}^{+}$to $\mathrm{CD}^{+} \mathrm{T}$-cell ratio was markedly increased in tcasp $8^{-/-}$spleens, LN, and in peripheral blood (PBL; Fig. 4C). The expression levels of CD3, TCR $\alpha \beta, \mathrm{CD} 69$, CD25, CD95L, CD44, and CD62L were equivalent in the mutant and control peripheral T-cells (Fig. 4D; data not shown). Intriguingly, an increase in the expression of CD95 was observed in tcasp $8^{-/-}$peripheral T-cells compared with controls (Fig. 4D). These data demonstrate that in contrast to thymocyte development, caspase 8 is required for the maintenance of $\mathrm{T}$-cell homeostasis. Specifically, the number of $\mathrm{CD}^{+}$, and to a lesser extent $\mathrm{CD}^{+}, \mathrm{T}$-cells is dramatically lower in tcasp $^{8^{-/}}$mice when compared with control siblings.

\section{Defective activation-induced expansion of peripheral T-cells deficient for caspase 8}

We investigated the effect of caspase 8 mutation in Tcells by assessing the ability of tcasp $8^{-/-} \mathrm{T}$-cells and Bcells to respond to activation stimuli ex vivo. Purified tcasp $8^{-/-}$T-cells display decreased levels of $\left[{ }^{3} \mathrm{H}\right]$ thymidine incorporation in response to activation mediated by anti-CD3 antibody, and the further addition of antiCD28 antibody or exogenous IL2 was not able to rescue T-cell expansion relative to control T-cells (Fig. 5A). In addition, $\left[{ }^{3} \mathrm{H}\right]$ thymidine incorporation was not rescued when mutant T-cells were stimulated with Phorbol Myristate Acetate (PMA) and Ionomycin, agents that bypass TCR:CD3 signaling and induce downstream messengers directly (Fig. 5B). In contrast, B-cells purified from tcasp $8^{-/-}$and control mice displayed similar responses to activation by stimuli ex vivo (Fig. 5C).

Cell cycle analysis was performed on purified T-cells that were stimulated for $0-72 \mathrm{~h}$ with anti-CD3 and antiCD28 antibodies (Fig. 5D). The proportion of T-cells in the $G_{0} / G_{1}, S$, and $G_{2} / M$ phases of the cell cycle were 
A

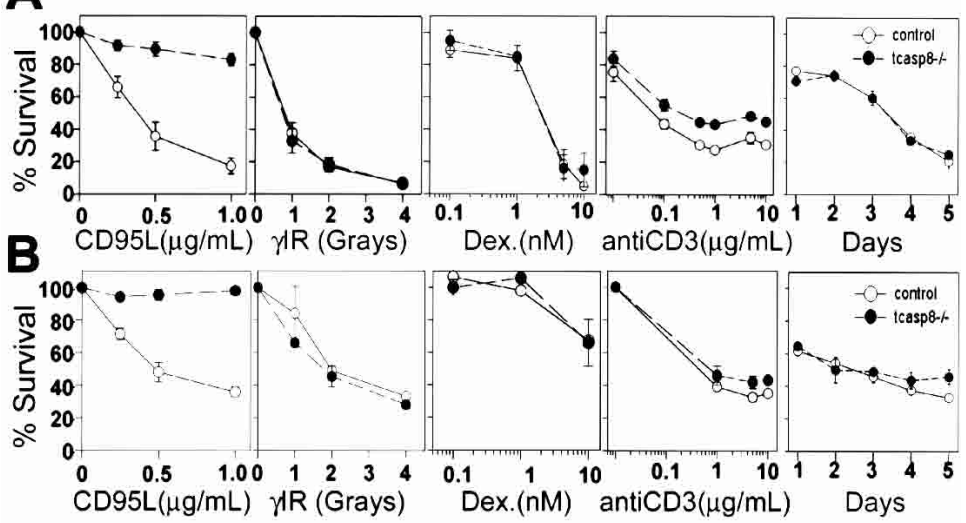

C
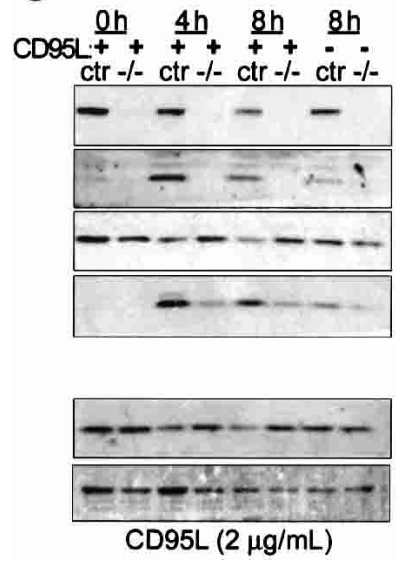

$\stackrel{0 \mathrm{~h}}{+}+\underline{4 \mathrm{~h}}+\underline{8 \mathrm{~h}}+\underline{8 \mathrm{~h}}$
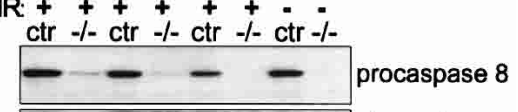

cleaved

caspase 8

procaspase 3

cleaved

caspase 3

p53

Bid

$\beta$-actin $\gamma \mathrm{IR}$ (4Grays)
Figure 3. Caspase 8 is required for CD95 but not mitochondrial-mediated apoptosis in the T-cell lineage. (A) Sensitivity of thymocytes to DR-mediated apoptosis induced by $\mathrm{CD} 95 \mathrm{~L}$ and mitochondrial-mediated apoptosis induced by ionizing radiation $(\gamma \mathrm{IR})$ or dexamethasone. Death induced by anti-CD3 and anti-CD28 antibodies and thymocyte death from neglect were also measured. Cell viability was determined $24 \mathrm{~h}$ after treatment ( $n \geq 3$ for each data point). (B) Activated Tcell death was studied in a similar fashion. $(C)$ Thymocytes were treated with $1 \mu \mathrm{g} / \mathrm{mL}$ CD95 ligand for the indicated times. Western blots were performed on lysates with the indicated antibodies. The anti-caspase 8 antibody detects the C-terminal p10 cleavage product of caspase 8 in control but not tcasp $8^{-1-}$ thymocytes. Caspase 3 cleavage was markedly reduced in tcasp $8^{-1-}$ thymocytes treated with CD95L but not in response to $\gamma$ IR. Similarly, loss of full-length Bid was reduced in tcasp $8^{-/-}$thymocytes in response to CD95L but not to $\gamma$ IR. p53 response to $\gamma$ IR was unaffected by caspase 8 mutation. similar in control and tcasp $8^{-/-}$backgrounds. Nevertheless, the $\mathrm{G}_{1}$ subpopulation, which represents dead $\mathrm{T}$-cells, was equivalent at $0 \mathrm{~h}$ but consistently greater in the tcasp $8^{-/-}$T-cells compared with controls at 48 and $72 \mathrm{~h}$ after stimulation (Fig. 5C). Together, these results demonstrate that defective activation-induced expansion observed specifically in T-cells derived from tcasp $8^{-/-}$mice is not the result of impaired cell cycling, but rather a result of a decreased cell survival.

\section{Activation of caspase 8 mutant T-cells}

To investigate the molecular mechanisms responsible for the defective homeostasis and survival observed in tcasp $8^{-/-}$T-cells, we examined different pathways that are induced in response to activation stimuli in vitro. We first assessed the effect of caspase 8 deficiency on TCR:CD3 signaling events by determining the levels of TCR:CD3-induced tyrosine phosphorylation. As shown in Figure 6A, no gross abnormalities in tyrosine phosphorylation were seen in tcasp $8^{-/-} \mathrm{T}$-cells stimulated by anti-CD3 antibody for $5 \mathrm{~min}$. NF-кB, a cellular factor that is translocated to the nucleus in response to activation stimuli, induces the transcription of genes that are essential for lymphocyte survival and activation, and for immune responses ( $\mathrm{Li}$ and Verma 2002). NF-кB activation in purified T-cells was analyzed by gel shift assays and was found to be similar in control and tcasp $8^{-/-} \mathrm{T}$ cells in response to anti-CD3 antibody with or without anti-CD28 antibody or exogenous IL-2, or stimulation by PMA and Ionomycin (Fig. 6B). Furthermore, caspase 8 mutation did not alter MAPK signaling in response to anti-CD3 antibody stimulation of T-cells as demonstrated by the similar phosphorylation of Erk1/2 (p42/44) in control and tcasp $8^{-1-}$ T-cells (Fig. 6C). IL-2 production was measured 48 and $72 \mathrm{~h}$ after T-cell stimulation with anti-CD3 and anti-CD28 antibodies (Fig. 6D). We detected less IL-2 in the supernatants of tcasp $8^{-/-}$T-cells relative to control T-cells stimulated for 48 and $72 \mathrm{~h}$ with anti-CD3 $(2$ or $5 \mu \mathrm{g} / \mathrm{mL})$ and anti-CD28 $(2 \mu \mathrm{g} / \mathrm{mL})$. This difference is likely a consequence of the decreased survival of tcasp $8^{-/-}$activated T-cells and, thus, the smaller number of cells present to secrete IL-2. Simultaneously, the expression levels of CD95 and the activation markers CD44, CD69, and CD25 (IL-2R $\alpha$ ) were also monitored and were found to be similarly up-regulated in tcasp $8^{-/-}$and control T-cells after 48 and $72 \mathrm{~h}$ of antiCD3 and anti-CD28 antibody stimulation (Fig. 6E). Our findings suggest that caspase 8 mutation does not affect proximal TCR:CD3 signaling, NF- $\mathrm{BB}$ nuclear translocation, or p42/44-MAPK activation. Furthermore, T-cells derived from $t c a s p 8^{-/-}$mice were observed to produce IL-2 and to up-regulate activation markers normally in response to activation stimuli in vitro. 
A
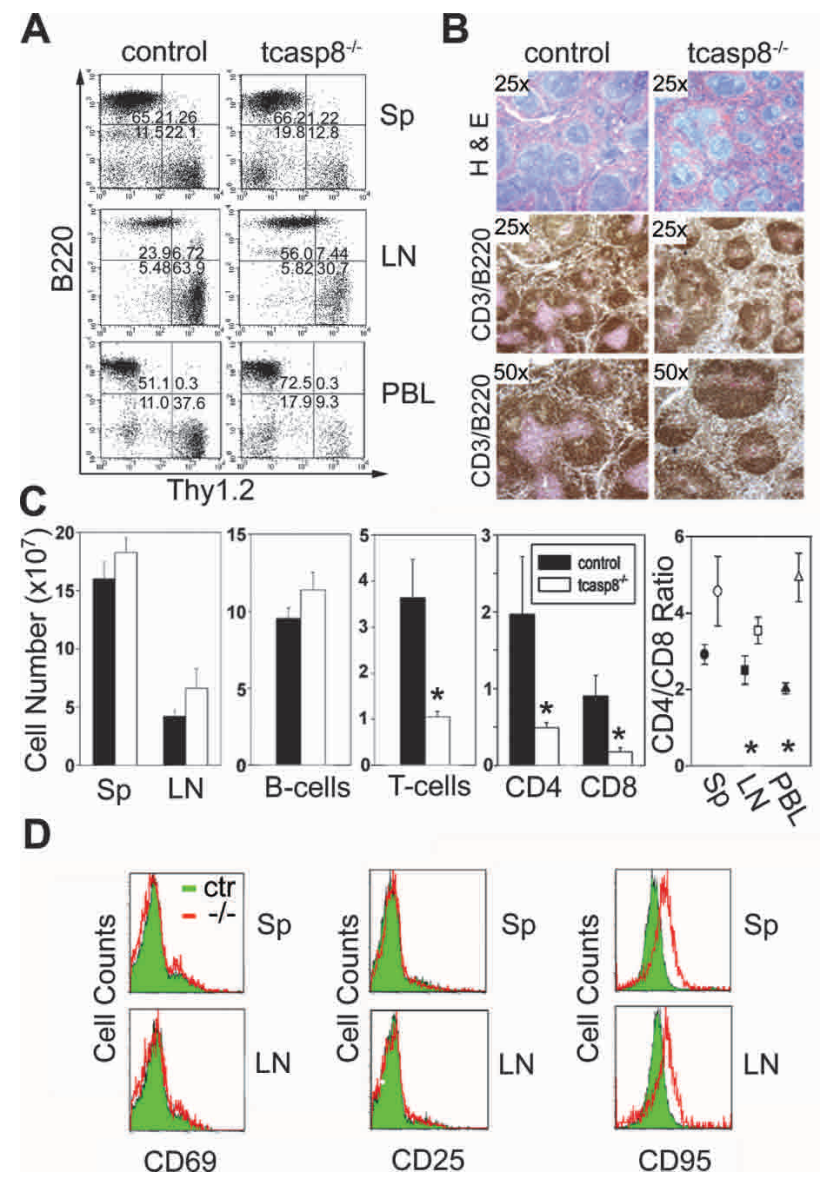

Figure 4. Caspase 8 is essential for T-cell homeostasis. $(A)$ Thy $1.2^{+}$-positive T-cell numbers are decreased in tcasp $8^{-/-}$compared with control spleen (Sp), lymph nodes (LN), and peripheral blood (PBL). Representative dot blots are shown. (B) Histological examination of $t c a s p 8^{-/-}$spleens identifies irregular T- and Bcell follicles characterized by a decreased presence of T-cells (anti-CD3, pink staining) and increased B-cells (anti-B220, brown staining) compared with spleen from control littermates. $(C)$ The mean total number of lymphocytes in the spleens was similar, yet the total number of Thy $1.2^{+} \mathrm{T}$-cells was significantly decreased in tcasp $8^{-/-}$spleens. Total $\mathrm{CD} 8^{+}$and to a lesser extent, $\mathrm{CD}^{+}{ }^{+} \mathrm{T}$-cells were reduced in spleen, $\mathrm{LN}$, and $\mathrm{PBL}$ from tcasp $8^{-/-}$mice. The CD4:CD8 ratio was markedly increased in spleen $(n=13), \mathrm{LN}(n=13)$, and PBL $(n=4) .{ }^{*}, p<0.05 .(D)$ CD69 and CD25 levels were normal on naive caspase 8-deficient peripheral T-cells; however, there was increased expression of CD95 on tcasp8 ${ }^{-1-}$ T-cells.

\section{Caspase 8 deficiency in T-cells leads to immunodeficiency}

Lymphocytic choriomeningitis virus (LCMV) infection of wild-type mice leads to expansion of $\mathrm{CD} 8^{+}$cytotoxic T-cells that are required for the clearing of the virus (Gallimore et al. 1998). To evaluate the effect of the caspase 8 deficiency on T-cell mediated immunity and responses to viral infection, tcasp $8^{-/-}$, control littermates, $\beta_{2} \mathrm{~m}^{-/-}$, and C57BL/6 mice were injected with LCMV. The proportion of $\mathrm{CD}^{+}$and $\mathrm{CD} 8^{+} \mathrm{T}$-cell populations in the peripheral blood of these mice was monitored by flow cy- tometry at regular time points after infection. A drastic expansion of $\mathrm{CD}^{+} \mathrm{T}$-cells in the peripheral blood was observed $6 \mathrm{~d}$ after infection in control and C57BL/6 mice but not in tcasp $8^{-/-}$or $\beta 2 \mathrm{~m}^{-/-}$mice (Fig. 7A). The impaired expansion of $\mathrm{CD} 8^{+} \mathrm{T}$-cells in peripheral blood and spleens of LCMV-infected tcasp $8^{-/-}$mice was accompanied by a decreased representation of $\mathrm{CD} 62 \mathrm{~L}^{\text {high }}$ CD44 ${ }^{\text {low }}$ (memory) T-cells in tcasp $8^{-/-}$mice compared with control littermates (data not shown). Furthermore, the ability of LCMV-infected tcasp $8^{-/-}$mice to generate CD8 ${ }^{+}$cytotoxic T-cells (CTL) specific for LCMV was abrogated (Fig. 7B,C; data not shown). These findings are consistent with the observation of persistence of the LCMV virus in tcasp $8^{-/-}$mice but not in control littermates (Fig. 7D). These findings demonstrate an absolute requirement for caspase 8 in $\mathrm{CD} 8^{+} \mathrm{T}$-cell mediated antiviral immunity.

\section{Discussion}

Dysregulation of apoptosis or programmed cell death is a predisposing factor for different human diseases including cancer and autoimmunity (Vaux and Flavell 2000). Emerging evidence indicates that the DR pathway, which is traditionally associated with apoptosis, is pivotal in the control of T-cell proliferation and activation (Budd 2002). Caspase 8 has been shown to be essential in the signaling of all known DRs including CD95, DR3, DR4, and DR5 (Ashkenazi 2002). The in vivo study of caspase 8 function in adult animals has been hampered by the early embryonic lethality associated with caspase 8 mutant mice (Varfolomeev et al. 1998; Sakamaki et al. 2002). Recently, caspase 8 mutation has been associated with immunodeficiency in humans (Chun et al. 2002). However, only two patients were available for that study, and redundancy between caspase 8 and caspase 10 function (which is not present in mouse) has not been clearly addressed. Furthermore, the "protease-dead" caspase 8 described in that study may still be able to function or interfere in some cellular processes. Therefore, the specific function of caspase 8 is still blurred. In our study using a conditional gene targeting approach in mice, we present evidence that supports a dual role for caspase 8 in apoptosis and T-cell response. We also demonstrate in vivo and in vitro that caspase 8 is essential for maintaining T-cell homeostasis and in preserving T-cellmediated immunity.

\section{Caspase 8 is not required for thymocyte development}

More than $95 \%$ of immature thymocytes are eliminated in the thymus (Egerton et al. 1990). These thymocytes die by apoptosis that is caused by negative selection leading to the elimination of autoreactive T-cells (Germain 2002). Alternatively, thymocytes die of neglect if they fail to go successfully through the positive selection process (Germain 2002). Previous studies have indicated that thymocyte development in mice was unaltered by mutation of caspases such as caspase 1, 2, 3, 9, 11, and 12 
A

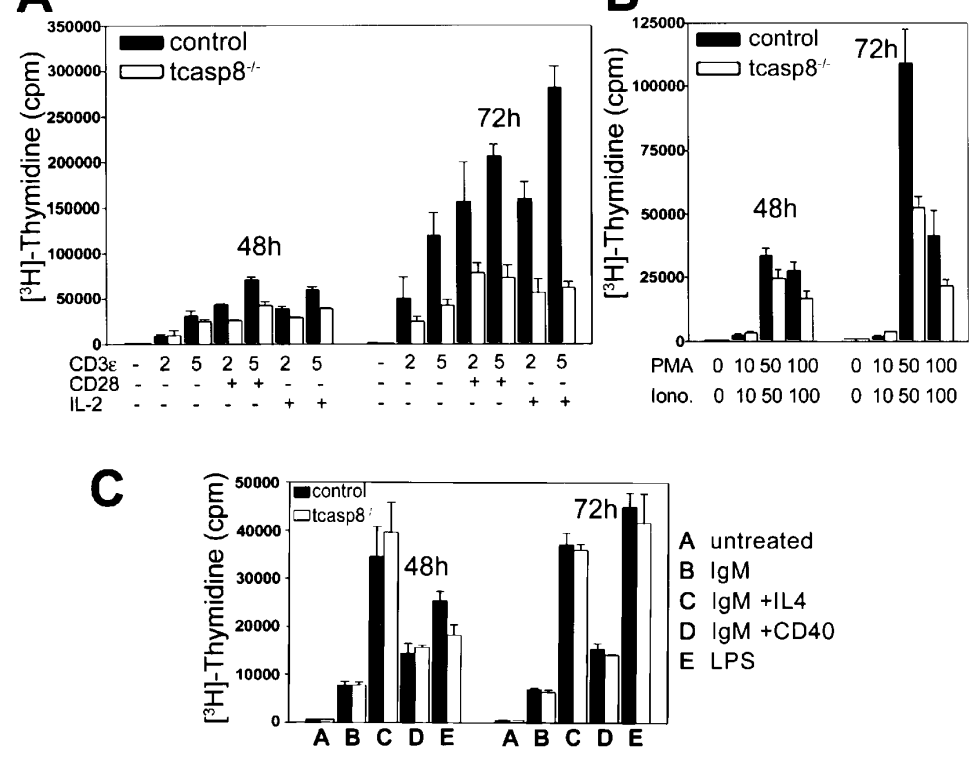

D

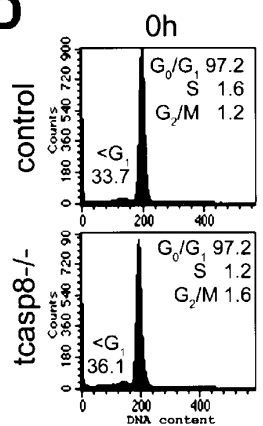

A untreated

D $\operatorname{lgM}+\mathrm{CD} 40$

E LPS

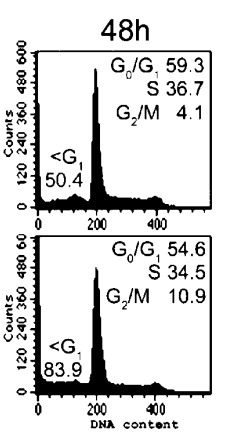

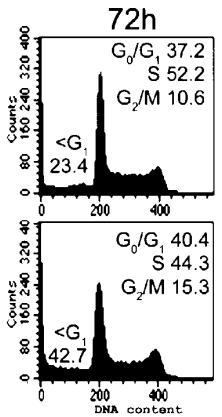

B
Figure 5. Defective cell growth of tcasp $8^{-/-}$T-cells. $(A)$ $\left[{ }^{3} \mathrm{H}\right]$ Thymidine incorporation in tcasp $8^{-/-}$and control purified T-cells after 48 or $72 \mathrm{~h}$ of stimulation with anti-CD3 (2 or $5 \mu \mathrm{g} / \mathrm{mL}$ ) with or without costimulation by anti-CD28 $(2 \mu \mathrm{g} / \mathrm{mL})$ or IL-2 (100 U/mL). Representative experiments are shown. $(B)\left[{ }^{3} \mathrm{H}\right]$ Thymidine incorporation in tcasp $8^{-/-}$and control purified T-cells after stimulation with PMA and ionomycin (concentrations in nanograms per milliliter). Representative experiments are shown. $(C)\left[{ }^{3} \mathrm{H}\right]$ Thymidine incorporation in B-cells purified from tcasp $8^{-1-}$ and control mice after 48 or $72 \mathrm{~h}$ of activation with various stimuli. $(D)$ The proportion of $T$-cells in $G_{0} / G_{1}, S$, and $G_{2} / M$ phases were similar in control and tcasp $8^{-/-}$backgrounds after antiCD3 and anti-CD28 stimulation. The larger $\mathrm{G}_{1}$ subpopulation in the cycling tcasp $8^{-/-}$T-cells at 48 and 72 $\mathrm{h}$ after stimulation indicates decreased survival of stimulated tcasp ${ }^{-1-}$ T-cells. $\mathrm{G}_{0} / \mathrm{G}_{1}, \mathrm{~S}$, and $\mathrm{G}_{2} / \mathrm{M}$ are calculated from the total number of cycling $\mathrm{T}$-cells. Sub- $G_{1}$ values represent the percentage of the total number of all cells cycling or dead.
(Kuida et al. 1995, 1996, 1998; Bergeron et al. 1998; Hakem et al. 1998; Wang et al. 1998; Woo et al. 1998; Nakagawa et al. 2000).

We show that caspase 8 is not required for thymocyte development as no differences were found in the number or distribution of thymocyte populations in caspase 8 mutants compared with control mice. This finding is reminiscent of the normal thymocyte development observed in lpr and gld mice, which carry mutations in CD95 and CD95L, respectively (Nagata and Suda 1995). However, it contrasts with the defects observed in early thymocyte development of FADD mutant mice (Walsh et al. 1998; Newton et al. 2000; Kabra et al. 2001). This finding suggests a caspase 8-independent function of FADD in regulating early thymocyte development. Furthermore, we show that caspase 8 deficiency does not protect thymocytes from in vitro death by neglect or in response to anti-CD3. Further investigation is required to determine an in vivo role for caspase 8 in thymocyte negative selection.

\section{Caspase 8 and apoptotic pathways}

We and others have demonstrated that targeted mutation of caspases involved in the mitochondrial-mediated apoptotic pathway do not affect the integrity of the DR pathway (Hakem et al. 1998; Kuida et al. 1998). However, mutations of caspase 1, caspase 3, or caspase 11 confer a partial resistance to CD95 killing of T-cell lineage (Kuida et al. 1995; Wang et al. 1998; Woo et al. 1998). Furthermore, the existence of an alternative caspase 8-independent CD95-induced death pathway has been proposed (Holler et al. 2000), raising the question of the extent of the importance of caspase 8 mutation on CD95-mediated apoptosis. Our data demonstrate that caspase 8 is essential for CD95-mediated cell death of thymocytes as well as activated T-cells. Furthermore, our data suggest that the existence of an alternate caspase 8-independent CD95 death pathway, in the Tcell lineage, is either unlikely or composes a very minor component of the CD95 death signaling pathway. In addition, our study clearly shows that caspase 8 is dispensable for anti-CD3-mediated thymocyte apoptosis as well as anti-CD3-mediated AICD, processes that are likely to be mediated by the BH3-only Bcl-2 family member Bim (Bouillet et al. 1999, 2002). Finally, we have demonstrated that caspase 8 mutation abrogates Bid processing in response to CD95. However, caspase 8 is not required for efficient Bid processing in response to stimuli that target the mitochondrial apoptotic pathway, nor is it 
Salmena et al.

Figure 6. Activation of tcasp $8^{-/-}$T-cells. A. The profile of tyrosine-phosphorylated proteins was similar in tcasp $8^{-/-}$and control T-cells activated with anti-CD3 antibody for $5 \mathrm{~min}$. (B) NF-кB activation analyzed by gel shift was found to be similar in control and tcasp $8^{-/-} \mathrm{T}$-cells in response to various stimuli. $(C)$ Baseline levels and phosphorylation of p42/44-MAPK (Erk1/2) following anti-CD3 activation of purified T-cells was similar in control and tcasp $8^{-/-}$T-cells. (D) IL-2 concentration in the supernatant of purified T-cells after 48 and $72 \mathrm{~h}$ of stimulation with anti-CD3 and anti-CD28 antibodies. A representative experiment is shown. $(E)$ The expression of CD95 and the activation markers CD44, CD69, and CD25 (IL-2R $\alpha$ ) were similarly upregulated on tcasp $8^{-/-}$and control T-cells at 48 and $72 \mathrm{~h}$ after anti-CD3 and anti-CD28 stimulation.
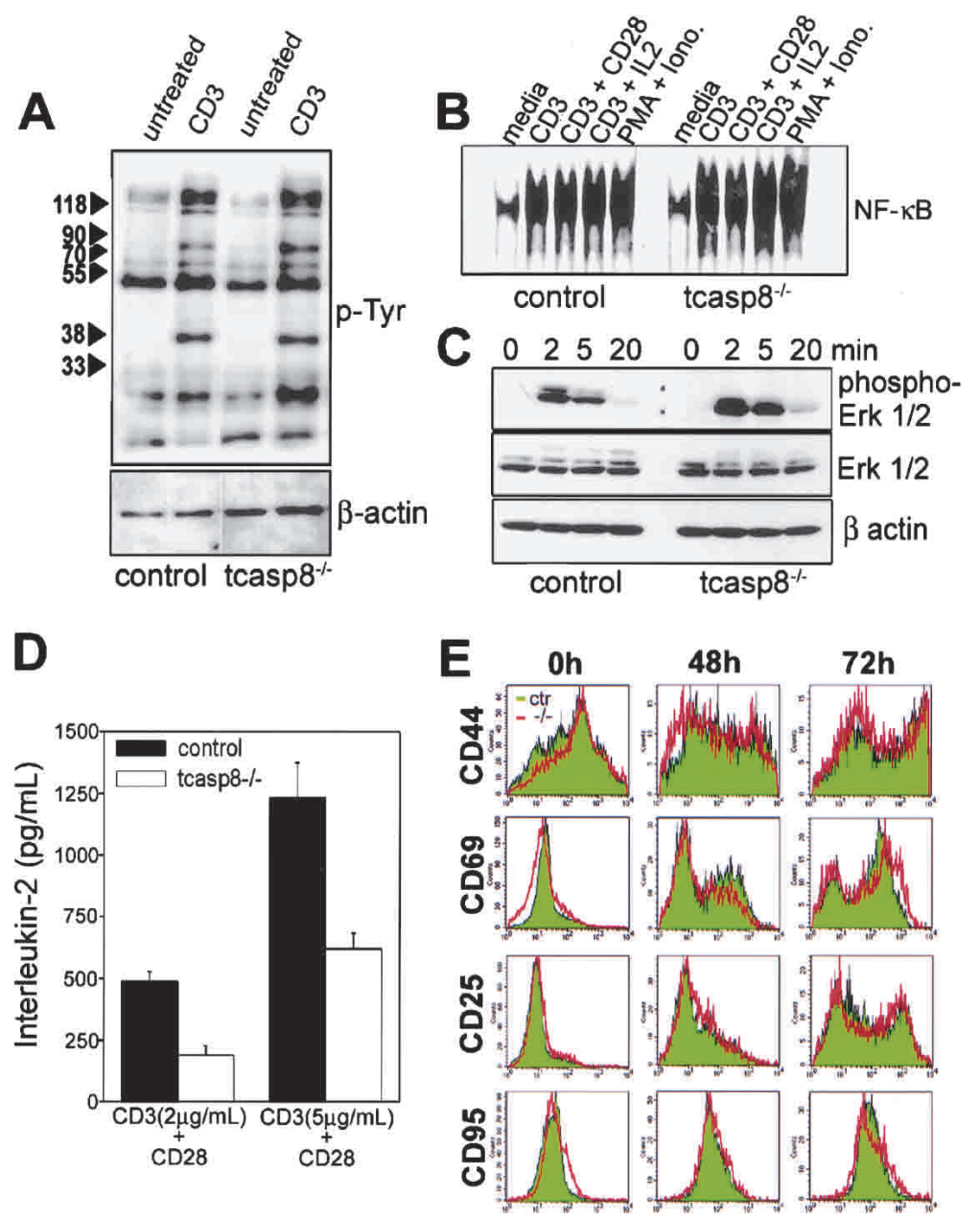

$72 h$
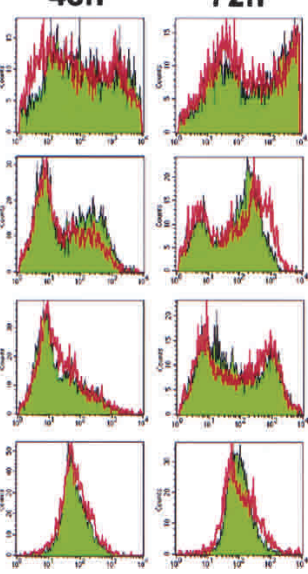

necessary for the activation of this apoptotic pathway in the T-cell lineage.

\section{Caspase 8 and T-cell homeostasis}

Mature peripheral T-cell numbers are maintained through a balance between thymic output and expansion and death of T-cells in the secondary lymphoid tissues (Jameson 2002; Khaled and Durum 2002). It is estimated that $10^{6} \mathrm{~T}$-cells are released from mouse thymus every day to the pool of peripheral T-cells and a similar number of cells are eliminated daily from this pool to maintain T-cell homeostasis (Khaled and Durum 2002). In contrast to previous investigations of caspase mutant mice (Zheng et al. 1999), we show here that caspase 8 deficiency perturbs the equilibrium of T-cell turnover, resulting in a significant depletion of peripheral T-cells. Deficiency in peripheral T-cells, particularly $\mathrm{CD}^{+}$, was previously observed in very young FADDdn, but not old mice (Walsh et al. 1998). In contrast, the profound depletion of caspase 8-deficient peripheral T-cells affects both $\mathrm{CD}^{+}$, and to a lesser extent $\mathrm{CD}^{+}$populations and is age-independent.

Maintenance of pools of naive and memory T-cells is influenced by various factors including cytokines and interaction of TCR-CD3 with the peptides-MHC (Rooke et al. 1997; Marrack et al. 2000; Leonard 2001; Polic et al. 2001; Jameson 2002; Khaled and Durum 2002). Both naive and memory T-cells deficient in caspase 8 may be at a homeostatic disadvantage owing to their impaired responses to TCR-CD3 and cytokines including IL-2 as indicated by their impaired growth in response to these stimuli ex vivo.

\section{Caspase 8 function in T-cell activation and proliferation}

To date, various studies suggest a link between proteins involved in the DR pathway and cellular proliferation (Budd 2002). CD95L was able to promote proliferation and increase IL-2 production in combination with suboptimal doses of CD3 stimulation (Suzuki and Fink 1998). c-FLIP transgenic T-cells showed an enhanced NF- $к \mathrm{~B}$ activation and IL-2 production, which increases T-cell proliferation (Lens et al. 2002). On the other hand, TCR-induced proliferation of naive T-cells was greatly impaired in FADD mutant mice (Newton et al. 1998; Walsh et al. 1998; Zhang et al. 1998) and in vitro inhibi- 
A

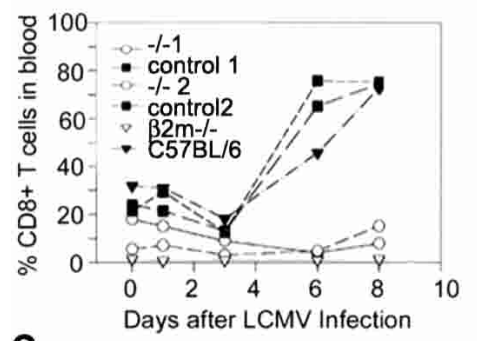

C

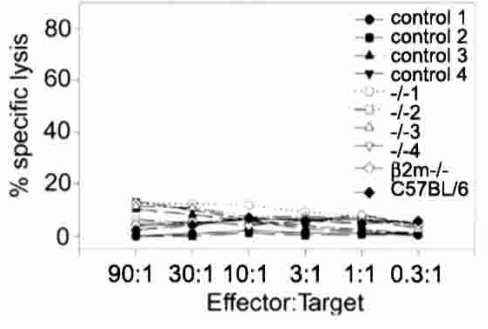

B

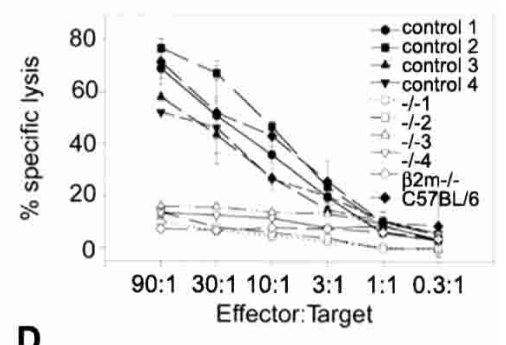

D

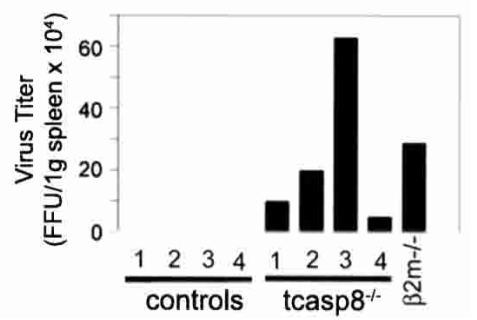

Figure 7. Defective T-cell response of tcasp $8^{-/-}$ mice to LCMV infection. (A) The expansion of CD8 ${ }^{+}$ $\mathrm{T}$-cells in peripheral blood was monitored by flow cytometry using specific antibodies for Thy1.2, CD4, and CD 8 on days $0,1,3,6$, and $8 .(B, C)$ The cytotoxic response of splenocytes was assessed $8 \mathrm{~d}$ after LCMV infection. EL4 cells were prepulsed with p33 (a specific LCMV peptide) or AV (a control peptide) and were used as target cells. (D) Viral titer was assessed from the spleens of mice $8 \mathrm{~d}$ after LCMV infection. tors of caspase 3 and caspase 8 are able to decrease IL-2 production, thereby reducing anti-CD3-mediated T-cell proliferation (Alam et al. 1999; Kennedy et al. 1999; Mack and Hacker 2002). In this study, we demonstrate the requirement for caspase 8 for optimal T-cell expansion. In vitro, expansion of tcasp $8^{-/-} \mathrm{T}$-cells in response to anti-CD3 alone is impaired. However, this defect is not associated with abnormal NF-кB or MAPK signaling, and it is costimulation-independent, as it is not rescued by addition of anti-CD28 or of exogenous IL-2. These findings are consistent with results observed in mice overexpressing a transgenic dominant-negative Fadd molecule in their T-cells (Newton et al. 2001). Furthermore, this defect was not accompanied by any significant differences in the tyrosine phosphorylation profile of T-cells stimulated in vitro with anti-CD3 antibody. Finally, T-cells derived from tcasp $8^{-/-}$mice were able to produce modest amounts of IL-2.

The mechanism whereby caspase 8 deletion affects activation-induced T-cell expansion is presently unclear. It was shown that caspase 8 and caspase 3 are activated in anti-CD3-stimulated T-cells (Alam et al. 1999; Kennedy et al. 1999|. Together with the evidence showing that proteins involved in the TCR signaling cascade such as Gads, SLP-76, LAT, SLAP-130/Fyb (Berry et al. 2001), vav1 (Hofmann et al. 2000), and HPK1 (Chen et al. 1999) are substrates for caspase processing, it is tempting to speculate that caspase 8 plays a role in maintaining optimal proximal signaling of the TCR-CD3 complex. Alternatively, caspase 8 may be required for modulation of proper cytokine responsiveness. This hypothesis is consistent with the ability of caspase 8 -deficient T-cells to produce IL-2, and their inability to respond to exogenous IL-2, as observed in our study. Therefore, tcasp $8^{-/-} \mathrm{T}$ cells may not be capable of sustaining their own survival through cytokine signaling. This lack of cytokine responsiveness may be responsible for the homeostatic imbalance that results in dramatically reduced T-cell numbers observed in the periphery of $t c a s p 8^{-/-}$mice.
Caspase 8 and immunodeficiency: effects of caspase 8 mutation in human and mouse

Immunodeficiency is associated with increased susceptibility to infections and can be grouped based on the defective function of T-cells, B-cells, and NK cells (Khaled and Durum 2002). Intriguingly, we demonstrate that caspase 8 mutation restricted to the T-cell lineage is sufficient to lead to immunodeficiency as indicated by the inability of $t c a s p 8^{-/-}$mice to clear LCMV viral infection. In mice, it has been shown that LCMV infection drives a potent expansion of $\mathrm{CD}^{+}$cells as it results in an $\sim 1000$-fold increase of the $\mathrm{CD}^{+}$pool of T-cells (Blattman et al. 2002). Remarkably, caspase 8-deficient T-cells are unable to produce this burst of proliferation, and the $\mathrm{CD}^{+} \mathrm{T}$-cell population does not expand in vivo in response to LCMV infection. Therefore, our study corroborates clinical studies that report that caspase 8 deficiency predisposes for immunodeficiency (Chun et al. 2002). More importantly, we demonstrate that caspase 8 deficiency restricted to T-cells is sufficient to bring about immunodeficiency as indicated by the profound decrease in the number of peripheral T-cells and the complete abrogation of T-cell-mediated immunity in response to viral infection in mutant mice.

In human patients, caspase 8 mutation completely abrogates IL-2 production in anti-CD3-stimulated T-cells. This defect was rescued by directly activating second messengers with PMA. In contrast, anti-CD3- and antiCD28-stimulated tcasp $8^{-/-}$T-cells do not exhibit an abrogation of IL-2 production, and their growth defect cannot be rescued either by PMA-ionomycin treatment or addition of exogenous IL-2. Furthermore, the up-regulation of CD95 and the activation markers CD25 and CD69 was defective in the human caspase 8-deficient $\mathrm{T}$-cells but not in murine tcasp $8^{-/-} \mathrm{T}$-cells. In contrast to the two caspase 8 mutant patients that exhibit a relatively normal total lymphocyte number /Chun et al. 2002), tcasp $8^{-/-}$mice exhibit a profound depletion of pe- 
ripheral T-cells. The simplest explanation for the differences observed in humans and mice is to attribute them to species differences. Nevertheless, these differences could be due to the limited number of caspase 8 patients studied, the presence of caspase 10 in human (and not in mice), and/or the presence of the caspase 8 mutation in all patient cells as contrasted to its restriction to T-cells in our study.

Our results support that in addition to its major role in apoptosis mediated by DRs, caspase 8 is essential for T-cell proliferation, immune responses, and in preventing immunodeficiency. Caspase 8 deficiency in the Tcell lineage results in a marked depletion of peripheral T-cells and a profound impairment of the in vivo immune response to viral infection. Furthermore, the tcasp $8^{-/-}$mouse may serve as a model to investigate the mechanisms that modulate lymphocyte homeostasis, a phenomenon that is poorly understood at the present time.

\section{Materials and methods}

\section{Construction of the targeting vector}

The targeting construct used to generate the caspase 8 conditional allele contains a neomycin (neo) and thymidine kinase (tk) cassette, short arm, long arm, and caspase 8 exons 3 and 4 flanked by lox $P$ sites. The short arm, exon 3 and 4 region, and long arm were PCR-amplified from a mouse 129Sv/J genomic library using the following primer sets: 5 '-CCCTCGAGGGTG GCCCAGGGTCACATTT-3' and 5'-CCGTCGACCCCGATC TCTCACAGGTG-3'; 5'-CCGGATCCGCCCTGAGTTTGGA AGAAGTA-3' and 5'-CCAGATCTCAAAGGCCAGAGCAGA GTTA-3'; 5'-CCCTCGAGGCTAGACACAAATCTTTTCCTG GAC- $3^{\prime}$ and $5^{\prime}$-CCCTCGAGATTGTTGATGATCAGACAG TATCCC-3', respectively.

\section{Generation of T-cell-specific caspase-8-deficient mice}

ES cells (E14K) were electroporated with the linearized targeting construct and cultured in the presence of $300 \mu \mathrm{g} / \mathrm{mL}$ G418 for 11 d. G418-resistant ES cells were screened for homologous recombination by PCR. Correctly targeted ES clones were verified by Southern analysis using probes corresponding to the $5^{\prime}$ - and 3 '-flanking regions, exons $3-4$, and neomycin coding region. Southern blots were performed on BamHI- and EcoRI-digested genomic DNA. The floxed neo-tk resistance cassette was removed from $t$ casp $8^{-f 13-4 ; n e o-t k / w t}$ ES clones by transient transfection with a $C M V$ promoter-driven construct encoding Cre recombinase to generate casp $8^{f 13-4 / w t}$ ES clones. ES cells that had lost the neo-tk cassettes but retained the floxed exons 3 and 4 were identified by Southern blot analysis. casp $8^{f 13-4 / w t}$ ES clones were microinjected into $\mathrm{C} 57 \mathrm{BL} / 6$ blastocysts to generate chimeric mice. Heterozygous (casp $\left.8^{\text {fl3-4/wt }}\right)$ mutant mice were generated by crossing chimeric mice (129/Ola $\times$ C57BL/6 background) to $\mathrm{C} 57 \mathrm{BL} / 6$ mice. Intercrossing of heterozygous casp $8^{f 13-4 / w t}$ mice generated homozygous casp $8^{f 13-4 / f 13-4}$ mice. To inactivate caspase 8 in the T-cell lineage, homozygous and heterozygous mice were crossed with LckCre transgenic mice (C57BL/6 background; Jackson Labs). Mice from these crosses in a $129 / \mathrm{Ola} \times \mathrm{C} 57 \mathrm{BL} / 6$ mixed background were intercrossed to generate casp $8^{f 13-4 / f 13-4}$; LckCre mice (T-cell-lineage-specific caspase 8 mutant mice; referred to in this paper as tcasp $8^{-/-}$.
The mutant phenotype was studied in a mixed 129/C57BL/6 genetic background in mice between 5 and 7 weeks of ages. No phenotypic differences were observed in casp $8^{w t / w t}$, casp $8^{f l 3-4 / w t}$, casp $8^{\text {fl3-4/f13-4 }}$, casp $8^{w t / w t}$; LckCre, and casp $8^{f 134 / w t}$; LckCre mice, and therefore they were used as experimental controls.

\section{Genotyping}

PCR genotyping of $t c a s p 8^{-/-}$mice was performed with primer 5'-CCAGGAAAAGATTTGTGTACT-3' and primer 5'-GGC CTTCCTGAGTACTGTCACCTGT-3'. PCR amplification of the wild-type caspase 8 allele produces a 650 -bp band, whereas the $\operatorname{casp} 8^{f 13-4}$ allele generates a band of $850 \mathrm{bp}$.

\section{cDNA generation and sequencing}

Total RNA was extracted from thymocytes $\left(1 \times 10^{7}\right)$ with TRIzol reagent (Life Technologies) and reverse transcribed with Superscript II (Life Technologies). Primers specific for exon 1 and exon 5 of caspase 8 were used to PCR-amplify a 375-bp product corresponding to wild-type caspase 8 , and a 183-bp product that corresponds to the recombined casp $8^{\Delta 3-4}$ allele. PCR products were cloned into Topo cloning vectors (Clontech) and sequenced using a CEQ 200XL DNA analysis instrument (Beckman-Coulter).

\section{Flow cytometry analysis}

Single-cell suspensions prepared from thymus, spleen, and lymph nodes (cervical, inguinal, axillary, brachial, and inguinal lymph nodes were pooled) and PBL were stained with antibody at $4^{\circ} \mathrm{C}$ in PBS $+10 \%$ FCS (GIBCO). The following antibodies were used to analyze T-cell populations: anti-CD4, anti-CD8, anti-CD3, anti-CD25 (IL2R), anti-CD69, anti-CD95, antiCD95L, anti-Thy1.2, anti-CD44, anti-TCR $\beta$, and anti-CD62L conjugated to allophycocyanin, phycoerythrin, fluorescein, perCP, or biotin (Pharmingen). Biotinylated antibodies were revealed by streptavidin-PerCP (Pharmingen). Lymphoctes were analyzed by flow cytometry (FACScalibur; Becton Dickenson) with CellQuest software (Applied Biosystems).

\section{Histological analyses}

Spleens were fixed in buffered formalin, processed for paraffinembedded sectioning at $5 \mu \mathrm{m}$ and stained by hematoxylin and eosin (Fisher). For immunohistochemistry, spleen sections were incubated with rat monoclonal anti-mouse B220 (Pharmingen) and rabbit polyclonal anti-mouse CD3 (DAKO) antibodies. The Liquid DAB Substrate Chromagen System (DAKO) and the Vector Red Alkaline phosphatase substrate kit revealed B220 and CD3 labeling, respectively. No background staining was observed with anti-CD3, anti-B220, or secondary antibody alone.

\section{Thymocyte apoptosis}

Thymocytes $\left(1.0 \times 10^{5}\right.$ cells $)$ were treated with apoptotic stimuli: CD95L (recombinant hCD8-mCD95L fusion protein; $0.25,0.5$, and $1.0 \mu \mathrm{g} / \mathrm{mL}$; Kayagaki et al. 1997), dexamethasone $(0.1,1,10$, and $100 \mathrm{nM}$; Sigma), $\gamma$-irradiation (1, 2, and $4 \mathrm{~Gy})$, and anti-CD $3 \varepsilon(0.01,0.1,1,5$, and $10 \mu \mathrm{g} / \mathrm{mL} ; 2 \mathrm{C} 11$ clone; Pharmingen) in combination with anti-CD28 (1 $\mu \mathrm{g} / \mathrm{mL}$; Pharmingen). Apoptosis and cell death were measured $24 \mathrm{~h}$ after treatment using the Annexin/PI Apoptosis Detection Kit (R\&D Systems) or 7-amino-actinomycin D (7AAD; Sigma). 


\section{Activation-induced cell death}

T-cells derived from spleen or lymph nodes were activated overnight in the presence of preplated anti-CD $3 \varepsilon(10 \mu \mathrm{g} / \mathrm{mL})$, and for $3 \mathrm{~d}$ in media with $100 \mathrm{U} / \mathrm{mL}$ IL-2. Viable, activated T-cells were isolated using Lympholyte $\mathrm{M}$ (Cedarlane), washed and $\left(1.0 \times 10^{5}\right.$ cells) replated in 24-well dishes in $1 \mathrm{~mL}$ of media supplemented with IL-2, and the cells were subjected to the following apoptotic stimuli (treatments were the same as above): CD95L, dexamethasone, $\gamma$-irradiation, and anti-CD3 (no CD28 was used to kill activated T-cells). Twenty-four hours following treatment, cell viability was determined using the Annexin/PI Apoptosis Detection Kit (R\&D Systems) or 7-amino-actinomycin D (7AAD; Sigma).

\section{T-cell purification, proliferation analysis, and IL-2 production}

T-cells were enriched from lymph nodes by either fluorescenceactivated cell sorting (FACS) or by negative selection of B-cells using anti-B220-bound magnetic beads (Dynal). All T-cell experiments were performed with purified T-cells with a purity $\geq 93 \%$. For proliferation analysis, $1.0 \times 10^{5}$ purified T-cells were placed into round-bottom 96-well plates in RPMI-1640 media containing $10 \%$ FCS and $0.1 \% \beta$-mercaptoethanol and stimulated in triplicate with soluable anti-CD3 $(2$ or $5 \mu \mathrm{g} / \mathrm{mL})$, with or without anti-CD28 $(2 \mu \mathrm{g} / \mathrm{mL})$, or IL-2 $(100 \mathrm{U} / \mathrm{mL})$ or phorbol 12-myristate 13 -acetate (PMA; $20 \mathrm{ng} / \mathrm{mL}$ ) plus ionomycin $(50$ $\mathrm{ng} / \mathrm{mL})$. T-cells were pulsed for the last $18 \mathrm{~h}$ with $1 \mu \mathrm{Ci}\left[{ }^{3} \mathrm{H}\right]$ thymidine (Amersham) per well and harvested at 48 and $72 \mathrm{~h}$ after treatment. For cell cycle determination, T-cells were fixed in $70 \%$ ethanol, and DNA was stained with $5 \mu \mathrm{g} / \mathrm{mL}$ propidium iodide (PI; Sigma) as previously described (Hakem et al. 1999). $\mathrm{G}_{1} / \mathrm{G}_{1}, \mathrm{~S}, \mathrm{G}_{2} / \mathrm{M}$, and Sub $\mathrm{G}_{1}$ values were determined by using ModFit LT analysis software (Verify Software House Inc.). IL-2 production was quantitated after 48 and $72 \mathrm{~h}$ of stimulation with anti-CD3 $(2$ or $5 \mu \mathrm{g} / \mathrm{mL})$ and anti-CD28 $(2 \mu \mathrm{g} / \mathrm{mL})$ using the mouse IL-2 Quantikine Immunoassay Kit (R\&D Systems).

\section{Electrophoretic mobility shift assay}

For EMSA, $6 \times 10^{6}$ purified T-cells, either untreated or stimulated for $6 \mathrm{~h}$ with the following treatments: anti-CD3 $(1 \mu \mathrm{g} / \mathrm{mL}$ immobilized), anti-CD3 $\varepsilon$ and anti-CD28 $(1 \mu \mathrm{g} / \mathrm{mL})$, anti-CD3 and IL-2 (100 U/mL), and phorbol 12-myristate 13-acetate (PMA; $50 \mathrm{ng} / \mathrm{mL}$ ) plus ionomycin $(50 \mathrm{ng} / \mathrm{mL})$. Nuclear extracts were analyzed for NF- $\mathrm{kB}$ activation as described previously (Jones et al. 2000).

\section{T-cell activation}

For T-cell activation, $6.0 \times 10^{6}$ purified $\mathrm{T}$ cells were stimulated with $5 \mu \mathrm{g} / \mathrm{mL}$ of anti-CD3 antibody and $5 \mu \mathrm{g} / \mathrm{mL}$ of cross-linking antibody (anti-hamster IgG; Jackson ImmunoResearch) at $37^{\circ} \mathrm{C}$ for $0,2,5$, and $20 \mathrm{~min}$. Cells were immediately lysed, and lysates were analyzed by Western blot.

\section{Western blots}

Thymocytes or T-cells were washed once in ice cold PBS and lysed on ice for $30 \mathrm{~min}$ in CHAPS lysis buffer (10 mM Tris at 7.5, $0.5 \%$ CHAPS, $1 \mathrm{mM} \mathrm{MgCl}_{2}, 1 \mathrm{mM}$ EGTA, $10 \%$ glycerol, 1 $\mathrm{mM}$ sodium o-vanadate, and $0.1 \mathrm{mg} / \mathrm{mL}$ Pefabloc) supplemented with one protease inhibitor cocktail tablet (Roche) per $10 \mathrm{~mL}$ of lysis buffer. Lysates were cleared of cellular debris by centrifugation at $15,000 \mathrm{rpm}$, at $4^{\circ} \mathrm{C}$ for $10 \mathrm{~min}$. Protein concentration was determined using the Bio-Rad Protein Assay (Bio-Rad). Thirty micrograms of protein was separated on $4 \%-$
$20 \%$ Tris Glycine gels (Novex). Antibodies were used at the following dilutions in $2.5 \%$ powdered milk (Carnation) in PBST: rabbit polyclonal anti-caspase 8 (epitope SNKDDRRNKGKQMP; amino acids $453-466$ of murine caspase $8 ; 1: 100)$, anti-Bid (1: 1000; R\&D Systems), anti-caspase 3 (1:500; Transduction Laboratories), anti-MAPK p42/44 (1:1000) and anti-phospho MAPK p42/44 (1:1000; Transduction Laboratories), anti-p53 (1:500; Novocastra), anti- $\beta$-actin (1:1000; Sigma), and anti-panPKC (1: $500)$ and anti-phosphotyrosine antibody 4G10 (1:1000; both from Upstate Biotechnology).

\section{LCMV infection and cytotoxicity assay}

Mice were immunized i.v. with 2000 PFU of LCMV (Armstrong strain). Eight days later, cytotoxicity assays were performed using splenocytes. Responders were incubated at $37^{\circ} \mathrm{C}$ for $5 \mathrm{~h}$ with $10^{4}$ EL4 target T-cells that had been pulsed with $10^{-5}$ M p33 peptide (KAVYNFATM) or AV (adenovirus) peptide (SGPSNTPPEI) and ${ }^{51} \mathrm{Cr}$ (NEN DuPont) at $37^{\circ} \mathrm{C}$ for $2 \mathrm{~h}$. Specific lysis was calculated as (experimental release - spontaneous release $/($ maximum release - spontaneous release $) \times 100$. For LCMV titration, spleens from infected mice were homogenized in balanced salt solution. Supernatant was diluted and added to MC57G cells. Following a 48-h incubation, cells were fixed in formalin and stained with anti-LCMV mAb (hybridoma kindly provided by R.M. Zinkernagel, Institute for Experimental Immunology, University Hospital, Zurich, Switzerland).

\section{Statistical analysis}

Data are reported as mean \pm SEM. $P$ values for statistical differences were determined using the Student's t-test. Values of $P<0.05$ were considered significant.

\section{Acknowledgments}

We thank Peter McPherson, Minna Woo, Jacinth Abraham, Sam Benchimol, and Josef Penninger for continuous helpful discussions and for critically reviewing the manuscript. L.S. is supported by the Canadian Institute of Health Research (K.M. Hunter Award). This work was supported by Amgen Inc. and by grants from the Canadian Institute of Health Research (MOP 36537) and the National Cancer Institute of Canada (TFPP 12000) to R.H.

The publication costs of this article were defrayed in part by payment of page charges. This article must therefore be hereby marked "advertisement" in accordance with 18 USC section 1734 solely to indicate this fact.

\section{References}

Alam, A., Cohen, L.Y., Aouad, S., and Sekaly, R.P. 1999. Early activation of caspases during $\mathrm{T}$ lymphocyte stimulation results in selective substrate cleavage in nonapoptotic cells. J. Exp. Med. 190: 1879-1890.

Ashkenazi, A. 2002. Targeting death and decoy receptors of the tumour-necrosis factor superfamily. Nat. Rev. Cancer 2: 420-430.

Bergeron, L., Perez, G.I., Macdonald, G., Shi, L., Sun, Y., Jurisicova, A., Varmuza, S., Latham, K.E., Flaws, J.A., Salter, J.C., et al. 1998. Defects in regulation of apoptosis in caspase-2deficient mice. Genes \& Dev. 12: 1304-1314.

Berry, D.M., Benn, S.J., Cheng, A.M., and McGlade, C.J. 2001. Caspase-dependent cleavage of the hematopoietic specific adaptor protein Gads alters signalling from the $\mathrm{T}$ cell receptor. Oncogene 20: 1203-1211. 
Blattman, J.N., Antia, R., Sourdive, D.J., Wang, X., Kaech, S.M., Murali-Krishna, K., Altman, J.D., and Ahmed, R. 2002. Estimating the precursor frequency of naive antigen-specific CD8 T cells. J. Exp. Med. 195: 657-664.

Bodmer, J.L., Holler, N., Reynard, S., Vinciguerra, P., Schneider, P., Juo, P., Blenis, J., and Tschopp, J. 2000. TRAIL receptor-2 signals apoptosis through FADD and caspase-8. Nat. Cell Biol. 2: 241-243.

Bouillet, P., Metcalf, D., Huang, D.C., Tarlinton, D.M., Kay, T.W., Kontgen, F., Adams, J.M., and Strasser, A. 1999. Proapoptotic Bcl-2 relative Bim required for certain apoptotic responses, leukocyte homeostasis, and to preclude autoimmunity. Science 286: 1735-1738.

Bouillet, P., Purton, J.F., Godfrey, D.I., Zhang, L.C., Coultas, L., Puthalakath, H., Pellegrini, M., Cory, S., Adams, J.M., and Strasser, A. 2002. BH3-only Bcl-2 family member Bim is required for apoptosis of autoreactive thymocytes. Nature 415: 922-926.

Budd, R.C. 2001. Activation-induced cell death. Curr. Opin. Immunol. 13: 356-362.

2002. Death receptors couple to both cell proliferation and apoptosis. J. Clin. Invest. 109: 437-441.

Budihardjo, I., Oliver, H., Lutter, M., Luo, X., and Wang, X. 1999. Biochemical pathways of caspase activation during apoptosis. Annu. Rev. Cell Dev. Biol. 15: 269-290.

Chen, Y.R., Meyer, C.F., Ahmed, B., Yao, Z., and Tan, T.H. 1999. Caspase-mediated cleavage and functional changes of hematopoietic progenitor kinase 1 (HPK1). Oncogene 18: 7370-7377.

Chun, H.J., Zheng, L., Ahmad, M., Wang, J., Speirs, C.K., Siegel, R.M., Dale, J.K., Puck, J., Davis, J., Hall, C.G., et al. 2002. Pleiotropic defects in lymphocyte activation caused by caspase- 8 mutations lead to human immunodeficiency. $\mathrm{Na}$ ture 419: 395-399.

Earnshaw, W.C., Martins, L.M., and Kaufmann, S.H. 1999. Mammalian caspases: Structure, activation, substrates, and functions during apoptosis. Annu. Rev. Biochem. 68: 383424.

Egerton, M., Scollay, R., and Shortman, K. 1990. Kinetics of mature T-cell development in the thymus. Proc. Natl. Acad. Sci. 87: 2579-2582.

Gallimore, A., Glithero, A., Godkin, A., Tissot, A.C., Pluckthun, A., Elliott, T., Hengartner, H., and Zinkernagel, R. 1998. Induction and exhaustion of lymphocytic choriomeningitis virus-specific cytotoxic T lymphocytes visualized using soluble tetrameric major histocompatibility complex class I-peptide complexes. J. Exp. Med. 187: 1383-1393.

Germain, R.N. 2002. T-cell development and the CD4-CD8 lineage decision. Nat. Rev. Immunol. 2: 309-322.

Gross, A., McDonnell, J.M., and Korsmeyer, S.J. 1999. BCL-2 family members and the mitochondria in apoptosis. Genes \& Dev. 13: 1899-1911.

Hakem, A., Sasaki, T., Kozieradzki, I., and Penninger, J.M. 1999. The cyclin-dependent kinase Cdk2 regulates thymocyte apoptosis. J. Exp. Med. 189: 957-968.

Hakem, R., Hakem, A., Duncan, G.S., Henderson, J.T., Woo, M., Soengas, M.S., Elia, A., de la Pompa, J.L., Kagi, D., Khoo, W., et al. 1998. Differential requirement for caspase 9 in apoptotic pathways in vivo. Cell 94: 339-352.

Hennet, T., Hagen, F.K., Tabak, L.A., and Marth, J.D. 1995. $\mathrm{T}$-cell-specific deletion of a polypeptide $\mathrm{N}$-acetylgalactosaminyl-transferase gene by site-directed recombination. Proc. Natl. Acad. Sci. 92: 12070-12074.

Hofmann, T.G., Hehner, S.P., Droge, W., and Schmitz, M.L. 2000. Caspase-dependent cleavage and inactivation of the Vav1 proto-oncogene product during apoptosis prevents IL-2 transcription. Oncogene 19: 1153-1163.

Holler, N., Zaru, R., Micheau, O., Thome, M., Attinger, A., Valitutti, S., Bodmer, J.L., Schneider, P., Seed, B., and Tschopp, J. 2000. Fas triggers an alternative, caspase-8-independent cell death pathway using the kinase RIP as effector molecule. Nat. Immunol. 1: 489-495.

Jameson, S.C. 2002. Maintaining the norm: T-cell homeostasis. Nat. Rev. Immunol. 2: 547-556.

Jones, R.G., Parsons, M., Bonnard, M., Chan, V.S., Yeh, W.C., Woodgett, J.R., and Ohashi, P.S. 2000. Protein kinase B regulates $\mathrm{T}$ lymphocyte survival, nuclear factor $\kappa \mathrm{B}$ activation, and Bcl-X(L) levels in vivo. J. Exp. Med. 191: 1721-1734.

Juo, P., Kuo, C.J., Yuan, J., and Blenis, J. 1998. Essential requirement for caspase-8/FLICE in the initiation of the Fas-induced apoptotic cascade. Curr. Biol. 8: 1001-1008.

Kabra, N.H., Kang, C., Hsing, L.C., Zhang, J., and Winoto, A. 2001. T cell-specific FADD-deficient mice: FADD is required for early $\mathrm{T}$ cell development. Proc. Nat1. Acad. Sci. 98: 6307-6312.

Kayagaki, N., Yamaguchi, N., Nagao, F., Matsuo, S., Maeda, H., Okumura, K., and Yagita, H. 1997. Polymorphism of murine Fas ligand that affects the biological activity. Proc. Natl. Acad. Sci. 94: 3914-3919.

Kennedy, N.J., Kataoka, T., Tschopp, J., and Budd, R.C. 1999. Caspase activation is required for $\mathrm{T}$ cell proliferation. J. Exp. Med. 190: 1891-1896.

Khaled, A.R. and Durum, S.K. 2002. Lymphocide: Cytokines and the control of lymphoid homeostasis. Nat. Rev. Immunol. 2: 817-830.

Krammer, P.H. 2000. CD95's deadly mission in the immune system. Nature 407: 789-795.

Kuida, K., Lippke, J.A., Ku, G., Harding, M.W., Livingston, D.J., Su, M.S., and Flavell, R.A. 1995. Altered cytokine export and apoptosis in mice deficient in interleukin-1 $\beta$ converting enzyme. Science 267: 2000-2003.

Kuida, K., Zheng, T.S., Na, S., Kuan, C., Yang, D., Karasuyama, H., Rakic, P., and Flavell, R.A. 1996. Decreased apoptosis in the brain and premature lethality in CPP32-deficient mice. Nature 384: 368-372.

Kuida, K., Haydar, T.F., Kuan, C.Y., Gu, Y., Taya, C., Karasuyama, H., Su, M.S., Rakic, P., and Flavell, R.A. 1998. Reduced apoptosis and cytochrome c-mediated caspase activation in mice lacking caspase 9. Cell 94: 325-337.

Kuwana, T., Mackey, M.R., Perkins, G., Ellisman, M.H., Latterich, M., Schneiter, R., Green, D.R., and Newmeyer, D.D. 2002. Bid, bax, and lipids cooperate to form supramolecular openings in the outer mitochondrial membrane. Cell 111: 331-342.

Lenardo, M., Chan, K.M., Hornung, F., McFarland, H., Siegel, R., Wang, J., and Zheng, L. 1999. Mature T lymphocyte apoptosis-Immune regulation in a dynamic and unpredictable antigenic environment. Annu. Rev. Immunol. 17: 221-253.

Lens, S.M., Kataoka, T., Fortner, K.A., Tinel, A., Ferrero, I., MacDonald, R.H., Hahne, M., Beermann, F., Attinger, A., Orbea, H.A., et al. 2002. The caspase 8 inhibitor c-FLIP(L) modulates $\mathrm{T}$-cell receptor-induced proliferation but not activation-induced cell death of lymphocytes. Mol. Cell. Biol. 22: 5419-5433.

Leonard, W.J. 2001. Cytokines and immunodeficiency diseases. Nat. Rev. Immunol. 1: 200-208.

Li, Q. and Verma, I.M. 2002. NF-кB regulation in the immune system. Nat. Rev. Immunol. 2: 725-734.

Luo, X., Budihardjo, I., Zou, H., Slaughter, C., and Wang, X. 1998. Bid, a Bcl2 interacting protein, mediates cytochrome $c$ release from mitochondria in response to activation of cell surface death receptors. Cell 94: 481-490. 
Mack, A. and Hacker, G. 2002. Inhibition of caspase or FADD function blocks proliferation but not MAP kinase-activation and interleukin-2-production during primary stimulation of T cells. Eur. J. Immunol. 32: 1986-1992.

Marrack, P., Bender, J., Hildeman, D., Jordan, M., Mitchell, T., Murakami, M., Sakamoto, A., Schaefer, B.C., Swanson, B., and Kappler, J. 2000. Homeostasis of $\alpha \beta$ TCR + T cells. Nat. Immunol. 1: 107-111.

Meier, P., Finch, A., and Evan, G. 2000. Apoptosis in development. Nature 407: 796-801.

Nagata, S. 1999. Fas ligand-induced apoptosis. Annu. Rev. Genet. 33: 29-55.

Nagata, S. and Suda, T. 1995. Fas and Fas ligand: lpr and gld mutations. Immunol. Today 16: 39-43.

Nakagawa, T., Zhu, H., Morishima, N., Li, E., Xu, J., Yankner, B.A., and Yuan, J. 2000. Caspase-12 mediates endoplasmicreticulum-specific apoptosis and cytotoxicity by amyloid- $\beta$. Nature 403: 98-103.

Newton, K., Harris, A.W., Bath, M.L., Smith, K.G., and Strasser, A. 1998. A dominant interfering mutant of FADD/MORT1 enhances deletion of autoreactive thymocytes and inhibits proliferation of mature T lymphocytes. EMBO J. 17: 706718.

Newton, K., Harris, A.W., and Strasser, A. 2000. FADD/MORT1 regulates the pre-TCR checkpoint and can function as a tumour suppressor. EMBO J. 19: 931-941.

Newton, K., Kurts, C., Harris, A.W., and Strasser, A. 2001. Effects of a dominant interfering mutant of FADD on signal transduction in activated T cells. Curr. Biol. 11: 273-276.

Polic, B., Kunkel, D., Scheffold, A., and Rajewsky, K. 2001. How $\alpha \beta$ T cells deal with induced TCR $\alpha$ ablation. Proc. Natl. Acad. Sci. 98: 8744-8749.

Rathmell, J.C. and Thompson, C.B. 2002. Pathways of apoptosis in lymphocyte development, homeostasis, and disease. Cell 109 Suppl: S97-S107.

Rathmell, J.C., Lindsten, T., Zong, W.X., Cinalli, R.M., and Thompson, C.B. 2002. Deficiency in Bak and Bax perturbs thymic selection and lymphoid homeostasis. Nat. Immunol. 3: 932-939.

Rooke, R., Waltzinger, C., Benoist, C., and Mathis, D. 1997. Targeted complementation of MHC class II deficiency by intrathymic delivery of recombinant adenoviruses. Immunity 7: 123-134.

Sakamaki, K., Inoue, T., Asano, M., Sudo, K., Kazama, H., Sakagami, J., Sakata, S., Ozaki, M., Nakamura, S., Toyokuni, S., et al. 2002. Ex vivo whole-embryo culture of caspase-8-deficient embryos normalize their aberrant phenotypes in the developing neural tube and heart. Cell Death Differ. 9: 1196-1206.

Salvesen, G.S. 1999. Caspase 8: Igniting the death machine. Struct. Fold. Des. 7: R225-R229.

Strasser, A., Harris, A.W., Huang, D.C., Krammer, P.H., and Cory, S. 1995. Bcl-2 and Fas/APO-1 regulate distinct pathways to lymphocyte apoptosis. EMBO J. 14: 6136-6147.

Straus, S.E., Sneller, M., Lenardo, M.J., Puck, J.M., and Strober, W. 1999. An inherited disorder of lymphocyte apoptosis: The autoimmune lymphoproliferative syndrome. Ann. Intern. Med. 130: 591-601.

Su, H., Mills, A.A., Wang, X., and Bradley, A. 2002. A targeted X-linked CMV-Cre line. Genesis 32: 187-188.

Suzuki, I. and Fink, P.J. 1998. Maximal proliferation of cytotoxic $\mathrm{T}$ lymphocytes requires reverse signaling through Fas ligand. J. Exp. Med. 187: 123-128.

Varfolomeev, E.E., Schuchmann, M., Luria, V., Chiannilkulchai, N., Beckmann, J.S., Mett, I.L., Rebrikov, D., Brodianski, V.M., Kemper, O.C., Kollet, O., et al. 1998. Targeted disruption of the mouse caspase 8 gene ablates cell death induction by the TNF receptors, Fas/Apo1, and DR3 and is lethal prenatally. Immunity 9: 267-276.

Vaux, D.L. and Flavell, R.A. 2000. Apoptosis genes and autoimmunity. Curr. Opin. Immunol. 12: 719-724.

Walsh, C.M., Wen, B.G., Chinnaiyan, A.M., O'Rourke, K., Dixit, V.M., and Hedrick, S.M. 1998. A role for FADD in T cell activation and development. Immunity 8: 439-449.

Wang, J., Zheng, L., Lobito, A., Chan, F.K., Dale, J., Sneller, M., Yao, X., Puck, J.M., Straus, S.E., and Lenardo, M.J. 1999. Inherited human caspase 10 mutations underlie defective lymphocyte and dendritic cell apoptosis in autoimmune lymphoproliferative syndrome type II. Cell 98: 47-58.

Wang, S., Miura, M., Jung, Y.K., Zhu, H., Li, E., and Yuan, J. 1998. Murine caspase-11, an ICE-interacting protease, is essential for the activation of ICE. Cell 92: 501-509.

Wang, X. 2001. The expanding role of mitochondria in apoptosis. Genes \& Dev. 15: 2922-2933.

Woo, M., Hakem, R., Soengas, M.S., Duncan, G.S., Shahinian, A., Kagi, D., Hakem, A., McCurrach, M., Khoo, W., Kaufman, S.A., et al. 1998. Essential contribution of caspase 3/CPP32 to apoptosis and its associated nuclear changes. Genes \& Dev. 12: 806-819.

Zhang, J., Cado, D., Chen, A., Kabra, N.H., and Winoto, A. 1998. Fas-mediated apoptosis and activation-induced T-cell proliferation are defective in mice lacking FADD/Mort1. Nature 392: 296-300.

Zheng, T.S., Hunot, S., Kuida, K., and Flavell, R.A. 1999. Caspase knockouts: Matters of life and death. Cell Death Differ. 6: 1043-1053.

Zornig, M., Hueber, A.O., and Evan, G. 1998. p53-dependent impairment of T-cell proliferation in FADD dominant-negative transgenic mice. Curr. Biol. 8: 467-470. 


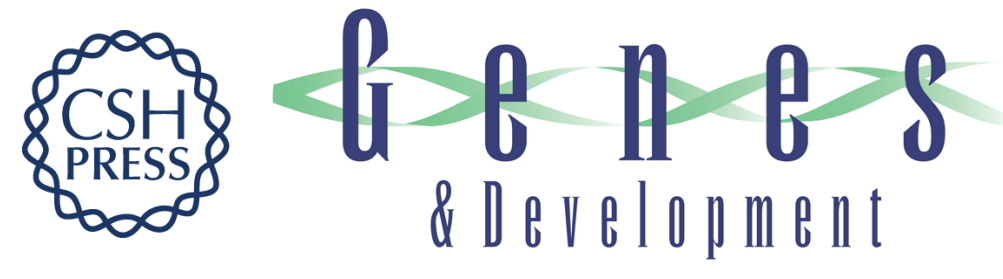

\section{Essential role for caspase 8 in T-cell homeostasis and T-cell-mediated immunity}

Leonardo Salmena, Benedicte Lemmers, Anne Hakem, et al.

Genes Dev. 2003, 17:

Access the most recent version at doi:10.1101/gad.1063703

References This article cites 68 articles, 21 of which can be accessed free at: http://genesdev.cshlp.org/content/17/7/883.full.htmI\#ref-list-1

\section{License}

Email Alerting

Receive free email alerts when new articles cite this article - sign up in the box at the top Service right corner of the article or click here.

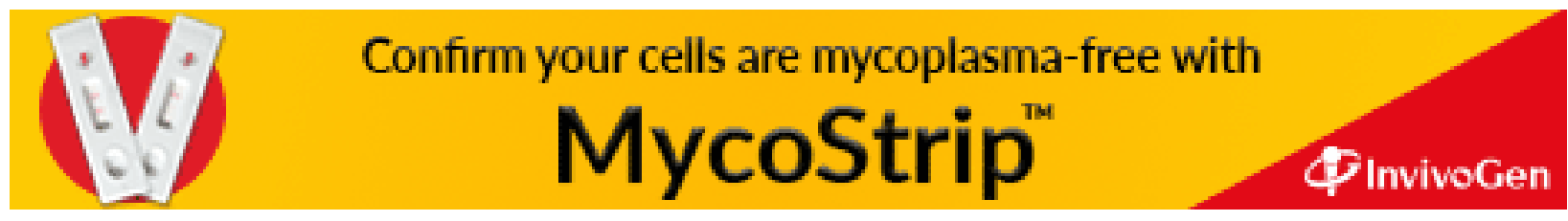

